\title{
Al-Chizan
}

ISSN 1907-0985, E ISSN 2442-8256

Vol. 15, No. 2, 2019, h. 292-315

DOI: https://doi.org/10.30603/am.v15i2.1380

\section{Penerapan Hukum dalam Pembebanan Nafkah Istri Pasca Perceraian di Pengadilan Agama Limboto}

\author{
Kartiningsi Dako
}

Pengadilan Agama Limboto

Email: kartiningsi_dako@yahoo.com

\begin{abstract}
This article discusses the livelihood of a post-divorce wife in the Limboto Religious Court by examining two decisions, namely Decision Number 419/Pdt.G/ 2016/PA.Lbt and Decision Number 618/Pdt.G/2018/PA.Lbt. These two decisions are different, although related to the burden of post-divorce wife's livelihood, so the problem in this article is how to apply the judge's law in determining the post-divorce wife's liability in the Limboto Religious Court? This research is a library research with a juridical normative approach. Data collected through literature study, then processed and analyzed descriptively qualitatively. The results showed the panel of judges of the Religious Court in the determination of the wife's post-divorce decision in the case of Decision Number 419/Pdt.G/2016/PA.Lbt and Decision Number 618/Pdt.G/2018/ $P A$.Lbt using the application of the law based on grammatical interpretation from the context of the husband's ability in terms of income, namely the actual ability and potential ability.
\end{abstract}

Keywords: Imposition, Income, Divorce, Limboto Religious Court

\section{Application of Law in Imposing Wife Livelihoods Post Divorce in Limboto Religious Court}

\begin{abstract}
Abstrak: Artikel ini mendiskusikan pembebanan nafkah istri pasca perceraian di Pengadilan Agama Limboto dengan menelaah dua hasil putusan, yaitu Putusan Nomor 419/Pdt.G/2016/PA.Lbt dan Putusan Nomor 618/Pdt.G/2018/PA.Lbt. Kedua putusan ini berbeda walaupun terkait dengan pembebanan nafkah istri pasca perceraian, sehingga permasalahan dalam artikel ini bagaimana penerapan hukum hakim dalam penentuan pembebanan nafkah istri pasca perceraian di Pengadilan Agama Limboto? Penelitian ini adalah penelitian kepustakaan yang dengan pendekatan normatif yuridis. Data yang dikumpulkan melalui studi kepustakaan, kemudian diolah dan dianalisis secara deskriptif kualitatif. Hasil penelitian menunjukkan majelis hakim Pengadilan Agama dalam penetapan putusan pembebanan nafkah istri pasca perceraian dalam kasus Putusan Nomor 419/Pdt.G/2016/PA.Lbt dan Putusan Nomor 618/Pdt.G/2018/ PA.Lbt menggunakan penerapan hukum berdasarkan interpretasi gramatikal dari konteks kemampuan suami dalam hal penghasilan, yaitu kemampuan secara aktual dan kemampuan secara potensial.
\end{abstract}

Kata Kunci: Pembebanan, Nafkah, Perceraian, Pengadilan Agama Limboto 


\section{A. Latar Belakang Masalah}

Perkawinan merupakan peristiwa suci dan bersifat sakral antara laki-laki dan perempuan yang dilaksanakan berdasarkan aturan-aturan agama, negara maupun adatistiadat masing-masing daerah. Oleh karena sifatnya yang sakral, maka persoalan perkawinan telah diatur secara jelas dan terperinci dalam sistem hukum Indonesia, baik itu hukum perundang-undangan nasional, hukum Islam maupun hukum adat. Hukum nasional di Indonesia misalnya mengaturnya dalam Undang-Undang Nomor 1 Tahun 1974 tentang Perkawinan (UUP) dan Kompilasi Hukum Islam (KHI).

Perkawinan dalam UUP pasal 1 disebutkan sebagai sebuah ikatan suci antara seorang pria dan seorang wanita yang dibangun dalam ikatan perjanjian sebagai suami istri untuk menciptakan kehidupan rumah tangga yang bahagia. ${ }^{1}$ Sedangkan dalam KHI pasal 2 disebutkan pernikahan adalah akad yang sangat kuat (mitsaqan ghalizan) untuk mentaati perintah Allah swt. dan sebagai perwujudan pelaksanaan ibadah. ${ }^{2}$

Sebuah perkawinan dalam pelaksanaannya adalah untuk mengciptakan kehidupan dalam pergaulan yang sempurna dan sebagai jalan mulia untuk mengatur kehidupan rumah tangga dan anak-anak yang kelak melahirkan penerus sebagai satu ikatan yang amat kuat guna memperkokoh persaudaraan antara kaum kerabat suami dengan kaum kerabat istri serta pertalian tersebut akan menjadi suatu jalan yang membawa kepada saling menolong antara satu kaum dengan yang lain, dan akhirnya rumah tangga tersebut menjadi sendi dasar dari susunan masyarakat.

Keluarga sebagai elemen dari masyarakat merupakan peletak pondasi dasar tentunya harus mempu menciptakan terlebih dahulu keluarga yang harmonis. Hal ini dikarenakan keluarga memegang peranan yang penting dalam pembinaan dan membentuk watak, moral dan perilaku setiap anggotanya. Artinya keluarga harmonis adalah keluarga yang mampu menciptakan sakinah, mawaddah wa rạmah dalam

${ }^{1}$ Lihat Republik Indonesia, Undang-Undang Nomor 1 Tahun 1979 tentang Perkawinan, dalam Zainal Abidin, Kumpulan Peraturan Perundang-Undangan dalam Lingkungan Peradilan Agama (Cet. 3; Jakarta: Yayasan al-Hikmah, 1993), 123.

${ }^{2}$ Republik Indonesia, Instruksi Presiden Nomor 1 Tahun 1999 tentang Kompilasi Hukum Islam, dalam Zainal Abidin, Kumpulan Peraturan Perundang-Undangan dalam Lingkungan Peradilan Agama, 307. 
perkawinannya. ${ }^{3}$ Manusia dalam pergaulan sehari-harinya tidak terlepas dari aturan dan norma hukum yang kesemuanya bertujuan mengatur kehidupan yang aman, damai dan tertib, tak terkecuali dalam hubungan perkawinan suami istri. Namun dalam pergaulan rumah tangga terkadang terjadi perselisihan, pertengkaran dan akhir berujung pada suatu keadaan yang menyebabkan suatu perkawinan tidak dapat dipertahankan lagi. Jika terjadi keadaan tersebut, maka kedua belah pihak keluarga melakukan upaya-upaya damai, namun terkadang juga upaya-upaya damai tersebut tidak membawa hasil yang maksimal, sehingga akhirnya jalan terakhir adalah perceraian.

Kehidupan berumah tangga tidak selamanya berjalan harmonis. Ketidakharmonisan ini dapat menjadi salah satu penyebab terputusnya perkawinan (perceraian). Perceraian boleh saja dilakukan jika pasangan suami dan istri tersebut tidak dapat hidup rukun lagi. Jika mempertahankan perkawinan mengakibatkan kerusakan total di antara keduanya, hubungan rumah tangga menjadi tidak baik dan terjadi permusuhan yang berlarut-larut, maka perceraian adalah solusi yang baik.

Putusnya perkawinan karena perceraian terjadi karena dua hal, yaitu talak dan gugatan perceraian. Seorang istri yang ditalak oleh suaminya, maka pihak istri masuk dalam masa menunggu atau tenggang waktu (iddah). Istri yang sementara menjalani masa iddah tidak boleh melangsungkan pernikahan dengan laki-laki lain.

Sebuah ikatan perkawinan tentunya menimbulkan hak dan kewajiban antara suami istri, begitu pula perceraian menimbulkan akibat hukum, baik suami istri maupun terhadap anak-anak yang dilahirkan dalam perkawinan. Akibat hukum yang ditimbulkan dikarenakan perceraian antara lain: pemberian mut'ah, melunasi utang mahar, selama masa iddah memberi nafkah, maskan dan kiswah, serta biaya pemeliharaan anak (hadanah) dan pendidikan anak. ${ }^{4}$

Lazimnya dalam tiap kasus perceraian yang dilakukan melalui Pengadilan Agama, baik itu melalui cerai talak maupun cerai gugat, di mana pihak Pengadilan

\footnotetext{
${ }^{3}$ Rizal Darwis, Nafkah Batin Isteri dalam Hukum Perkawinan (Gorontalo: Sultan Amai Press, 2015), 2.

${ }^{4}$ Republik Indonesia, Instruksi Presiden Nomor 1 Tahun 1991 tentang Kompilasi Hukum Islam, pasal 149, 156. Lihat pula Republik Indonesia, Undang-Undang Nomor 1 Tahun 1974 tentang Perkawinan, pasal 41.
} 
Agama dalam putusannya akan membebankan kepada mantan suami pemberian mut'ah, melunasi utang mahar, selama masa iddah memberi nafkah, maskan dan kiswah, serta biaya pemeliharaan anak (hadanah), pendidikan anak pasca perceraian.

Pengadilan Agama merupakan salah satu lembaga peradilan di bawah Mahkamah Agung yang memiliki kekuasaan kehakiman yang merdeka dalam penyelenggaraan Peradilan guna menegakkan hukum dan keadilan dengan tugas dan kewenangan memeriksa, memutus dan menyelesaikan perkara di bidang: perkawinan, waris, wasiat, hibah, wakaf, zakat, infaq, shadaqah dan ekonomi syari'ah. ${ }^{5}$

Hakim merupakan unsur pokok dalam Pengadilan, bahkan hakim identik dengan Pengadilan itu sendiri. Kebebasan kekuasaan kehakiman seringkali identik dengan kebebasan hakim. Begitu pula keputusan Pengadilan identik dengan keputusan hakim. Olehnya itu, penegakan hukum dan keadilan dapat tercapai jika kemampuan dan kearifan hakim dalam merumuskan keputusan dapat mencerminkan keadilan. ${ }^{6}$ Pengadilan dan para hakim wajib mengatasi segala hambatan dan rintangan untuk tercapainya Peradilan yang sederhana, cepat dan biaya ringan, ${ }^{7}$ baik yang berupa teknis maupun yuridis. Di sinilah kemampuan dari majelis hakim untuk dapat menemukan hukum dalam penyelesaian kasus yang masuk dan diterima oleh pihak Pengadilan Agama, khususnya dalam perkara pembebanan nafkah istri pasca perceraian.

Wilayah Pengadilan Tinggi Agama Gorontalo membawahi 6 Pengadilan Agama tingkat pertama, yaitu Pengadilan Agama Gorontalo, Pengadilan Agama Limboto, Pengadilan Agama Tilamuta, Pengadilan Agama Marisa, Pengadilan Agama Suwawa dan Pengadilan Agama Kwandang. Berdasarkan kewenangan tersebut, maka khusus Pengadilan Agama Limboto telah menerima dan memutus perkara perceraian, baik cerai talak maupun cerai gugat. Pada tahun 2008, perkara cerat talak yang diputus sebanyak 166 perkara, perkara cerai gugat sebanyak 497 perkara, dan yang didalamnya terdapat pembebanan nafkah istri pada perkara cerai talak sebanyak 19 perkara dan pada cerai gugat sebanyak 13 perkara.

\footnotetext{
${ }^{5}$ Republik Indonesia, Undang-Undang Nomor 3 Tahun 2006 tentang Perubahan Atas UndangUndang Nomor 7 Tahun 1989 tentang Peradilan Agama, pasal 49.

${ }^{6}$ Cik Hasan Bisri, Peradilan Agama di Indonesia (Jakarta: Raja Grafindo Persada, 2003), 193.

${ }^{7}$ Republik Indonesia, Undang-Undang Nomor 48 Tahun 2009 tentang Kekuasaan Kehakiman, pasal 4.
} 
Kajian terhadap dua putusan yang memutus perkara mengenai pembebanan nafkah istri pasca perceraian dengan pertimbangan yang berbeda yakni Putusan Nomor 419/Pdt.G/2016/PA.Lbt dan Putusan Nomor 618/Pdt.G/2018/PA.Lbt. Pada putusan pertama suami dibebankan untuk membayar sejumlah nafkah kepada istri berdasarkan kemampuan riil dari suami sedangkan pada putusan yang kedua pembebanan kepada suami didasarkan pada kemampuan riil dan juga kemampuan potensial suami.

Pada putusan pertama suami berprofesi sebagai seorang PNS sedangkan pada putusan kedua suami berprofesi sebagai kuli bangunan. Sebagian besar masyarakat beranggapan bahwa pegawai negeri sipil merupakan profesi yang bergengsi dan memiliki penghasilan yang besar sehingga PNS menjadi profesi yang paling diinginkan oleh banyak orang.lain halnya kuli bangunan, bagi kebanyakan orang bekerja sebagai kuli bangunan bukan sesuatu yang diharapkan karena penghasilannya tidak tetap. Sepertinya pandangan demikian tidak berlaku bagi hakim yang memutus kedua perkara tersebut, karena pada kenyataannya suami yang berprofesi sebagai PNS dibebankan untuk membayar nafkah istri pasca perceraian dalam nilai yang lebih sedikit daripada suami yang berprofesi sebagai kuli bangunan. Hal inilah menjadi kontradiktif terhadap kemampuan suami dalam memberikan nafkah isteri pasca perceraian.

\section{B. Penemuan Hukum dalam Putusan Hakim}

Hakim dalam melaksanakan pemeriksaan dan pemutusan perkara terkadang menghadapi suatu kenyataan bahwa hukum yang sudah ada tidak dapat menjawab dan menyelesaikan sengketa yang dihadapi secara pas. Olehnya itu hakim harus mencari kelengkapannya dengan melakukan penemuan hukum tersebut. ${ }^{8}$ Hal ini dikarenakan manusia dalam menjalani kehidupannya melakukan kegiatan yang sangat luas, tidak terhitung jumlah dan jenisnya, sehingga tidak mungkin tercakup dalam suatu hukum dan perundang-undangan yang tuntas dan jelas. Tidak ada hukum dan peraturan perundang-undangan yang lengkap selengkap-lengkapnya dan yang jelas sejelasjelasnya. Oleh karena hukumnya tidak jelas, maka harus dicari dan ditemukan. ${ }^{9}$

\footnotetext{
${ }^{8}$ Sudikno Mertokusumo dan A. Pitlo, Bab-Bab tentang Penemuan Hukum (Jakarta: PT Citra Aditya Bakti, 1993), 10.

${ }^{9}$ Ibid., 37.
} 
Hakim sebelum melakukan penemuan hukum haruslah menggunakan hukum tertulis terlebih dahulu, tetapi apabila hukum tertulis tersebut ternyata tidak tepat dan cukup, maka hakim hendaknya mencari dan menemukan hukum itu dari sumbersumber hukum lainnya. ${ }^{10}$ Sumber-sumber hukum lainnya tersebut, yaitu: yurisprudensi, doktrin, traktat, kebiasaan atau hukum tidak tertulis. ${ }^{11}$

Peristilahan penemuan hukum memiliki banyak arti, ada yang mengartikan pelaksanaan hukum, penerapan hukum dan penciptaan hukum. ${ }^{12}$ Istilah pelaksanaan hukum cenderung berarti menjalankan peraturan hukum tanpa adanya suatu sengketa atau pelanggaran. Hal ini meliputi pelaksanaan hukum yang dilakukan oleh warga negara setiap hari yang disadari atau tidak. Selain itu, pelaksanaan hukum dapat terjadi bersamaan dengan adanya sengketa atau pelanggaran, yaitu pelaksanaannya dilakukan oleh hakim, dan ini juga disebut dengan istilah penegakan hukum.

Istilah penerapan hukum berarti menerapkan peraturan hukum yang abstrak terhadap peristiwanya. Penerapan hukum terhadap peristiwa konkrit secara langsung tidak dimungkinkan karena peristiwa konkret harus dijadikan peristiwa hukum terlebih dahulu, sehingga peraturan hukumnya dapat diterapkan. Sedangkan istilah penciptaan hukum kiranya kurang tepat, karena terkesan bahwa hukum sama sekali belum ada, kemudian diciptakan. Hukum tidaklah selalu dalam bentuk kaedah, baik tertulis maupun tidak, tetapi juga dalam bentuk perilaku dan peristiwa.

Peraturan perundang-undangan adalah acuan yang digunakan hakim dalam menyelesaikan sengketa, dalam artian undang-undang tersebut diterapkan, namun selain undang-undang, juga yurisprudensi dapat dijadikan pedoman yang merupakan hasil putusan. Sebuah kasus dalam penyelesaian sengketa tidak dapat dihindari manakala terminologi yang digunakan oleh undang-undang tidak jelas, undang-undang tidak mengatur persoalan yang dihadapi atau undang-undang yang ada bertentangan

\footnotetext{
${ }^{10}$ Lihat Republik Indonesia, Undang-Undang Nomor 48 Tahun 2009 tentang Kekuasaan Kehakiman, pasal 10. Lihat pula Mertokusumo dan Pitlo, Bab-Bab tentang Penemuan Hukum, 8.

${ }^{11}$ Mertokusumo dan Pitlo, Bab-Bab tentang Penemuan Hukum, 8. Lihat juga Sudikno Mertokusumo, Penemuan Hukum: Sebuah Pengantar, Ed. II (Cet. VI; Yogyakarta: Liberty, 2009), 18.

${ }^{12}$ Sudikno Mertokusumo memberikan 5 istilah yang sering dikaitkan dalam kegiatan penemuan hukum, yaitu pembentukan hukum (rechtsvorming), penerapan hukum (rechtstoepassing), pelaksanaan hukum (rechtshandhaving), penciptaan hukum (rechtschepping), penemuan hukum (rechtsvinding). Lihat Mertokusumo, Penemuan Hukum: Sebuah Pengantar, 47-48.
} 
dengan situasi yang dihadapi. Oleh karena itulah, hakim dalam hal ini lalu melakukan pembentukan hukum (rechtvorming), analogi (rechtsanalogie), penghalusan hukum (rechtverfijning), atau penafsiran (interpretative). Kegiatan tersebut dalam sistem hukum kontinental disebut sebagai penemuan hukum (rechtsvinding). ${ }^{13}$

Sutiyoso mengemukakan bahwa penemuan hukum itu bukan hukumnya tidak ada, tetapi hukumnya sudah ada, namun masih perlu digali, dicari dan ditemukan untuk diterapkan dalam peristiwa konkret. ${ }^{14}$ Kehadiran penemuan hukum dalam ilmu hukum memberi solusi antara pandangan legisme, begriffsjurisprudenz yang terlalu tajam dalam menyikapi pandangannya dalam menyelesaikan persoalan hukum. ${ }^{15}$

Penemuan hukum merupakan aliran yang menyatakan bahwa hakim terikat pada undang-undang, tetapi tidaklah seketat seperti menurut ajaran legisme, yaitu hakim juga memiliki kebebasan. Namun kebebasan hakim dalam pelaksanaan tugas disebut sebagai kebebasan terikat atau keterikatan yang bebas. ${ }^{16}$ Hal ini berarti hakim berperan dalam penemuan hukum berdasarkan tuntutan zaman.

Eksistensi penemuan hukum begitu mendapatkan perhatian yang berlebih, karena penemuan hukum dirasa mampu memberikan suatu putusan yang dinamis dengan memadukan aturan yang tertulis dan aturan yang tidak tertulis. Penemuan hukum diartikan sebagai wadah ijtihad hakim dalam memberikan keputusan yang memiliki jiwa tujuan hukum, sehingga penemuan hukum dirasa memiliki corak yang indah yang menjelma menjadi suatu putusan hakim yang didambakan.

Scholten sebagaimana dikutip Ali menjelaskan penemuan hukum bukan hanya penerapan hukum atau peraturan pada peristiwanya, dimana terkadang atau seringkali terjadi peraturannya harus ditemukan, baik melalui jalan interpretasi maupun jalan analogi ataupun pengkonkretan hukum. ${ }^{17}$ Senada dengan Sholten, Panggabean juga

\footnotetext{
${ }^{13}$ Peter Mahmud Marzuki, Pengantar Ilmu Hukum, Edisi Revisi (Jakarta: Kencana, 2008), 282.

${ }^{14}$ Bambang Sutiyoso, Metode Penemuan Hukum (Yogyakarta: UII Press, 2012), 53.

${ }^{15}$ Aliran begriffsjurisprudenz merupakan aliran yang memperbaiki aliran legisme. Aliran ini mengajarkan bahwa sekalipun undang-undang tidak lengkap, tetapi undang-undang masih bisa menutupi kekurangan-kekurangannya sendiri, karena undang-undang memiliki daya meluas. Penggunaan hukum logika yang dinamakan silogisme menjadi dasar aliran ini, tujuan dari aliran ini ialah bagimana kepastian hukum dapat terwujud. Lihat Ahmad Ali, Menguak Tabir Hukum, Edisi Kedua (Jakarta: Kencana, 2015), 155.

${ }^{16}$ Ibid., 154.

${ }^{17}$ Ahmad Ali, Menguak Tabir Hukum, 154.
} 
mengartikan penemuan hukum sebagai proses konkretisasi terhadap peraturan hukum yang bersifat umum dengan mencermati peristiwa konkret yang terjadi dalam perkara tersebut. $^{18}$

Penemuan hukum menurut Mertokusumo adalah proses pembentukan hukum oleh hakim atau petugas-petugas hukum lainnya yang diberi tugas menerapkan hukum terhadap peristiwa-peristiwa hukum konkrit. Jadi, yang penting dalam penemuan hukum adalah mencarikan atau menentukan hukumnya untuk peristiwa konkrit. ${ }^{19}$ Menurut Hidayat, penemuan hukum dapat diartikan sebagai tindakan untuk menyisiasati terjadinya kesenjangan dalam undang-undang (legal gap) yang terjadi akibat undang-undang yang cepat atau lambat akan tertinggal oleh fakta seiring berubahnya tananan sosial tempat hukum itu hidup di dalam alam kenyataan. Legal gap yang dimaksud antara hukum di atas kertas (law in the books), dan hukum yang hidup dalam kenyataan (law in action). ${ }^{20}$

Penyebab terjadinya legal gap dikarenakan dalam penyusunan peraturan perundang-undangan, baik oleh legislatif maupun eksekutif memerlukan waktu yang panjang, sehingga pada saat peraturan perundang-undangan tersebut dinyatakan berlaku, maka hal atau keadaan yang diatur oleh peraturan tersebut sudah berubah. Selain itu, kekosongan hukum dapat terjadi jika keadaan atau sesuatu yang terjadi belum diatur dalam peraturan-perundang-undangan atau sekalipun sudah diatur, namun tidak jelas atau bahkan tidak lengkap. Hal ini sebenarnya selaras dengan pameo yang menyatakan bahwa "terbentuknya suatu peraturan perundang-undangan senantiasa tertinggal atau terbelakang dibandingkan dengan kejadian-kejadian dalam perkembangan masyarakat.",21

Persoalan inilah yang kemudian menjadikan adanya penemuan hukum yang dilakukan oleh para hakim dalam menyelesaikan persoalan-persoalan yang terjadi di masyarakat, sehingga melahirkan sebuah keadilan yang dapat dipertanggungjawabkan

${ }^{18}$ H.P. Panggabean, Penerapan Teori Hukum dalam Sistem Peradilan Indonesia (Bandung: PT. Alumni, 2014), 217.

${ }^{19}$ Mertokusumo, Penemuan Hukum: Sebuah Pengantar, 49.

${ }^{20}$ Arif Hidayat, "Penemuan Hukum Melalui Penafsiran Hakim dalam Putusan Pengadilan," Pandecta, Volume 8, Nomor 2, Juli 2013; 154; https://doi.org/10.15294/pandecta.v8i2.2682

${ }^{21}$ Muhammad Syukri Albani Nasution, Hukum dalam Pendekatan Filsafat (Cet. I; Jakarta: Kencana, 2016), 286. 
secara hukum sesuai fungsinya. Hukum berfungsi sebagai alat untuk melindungi kepentingan manusia atau sebagai perlindungan kepentingan manusia. Ini merupakan upaya yang semestinya dilakukan guna melindungi kepentingan manusia dengan jalan hukum harus dilaksanakan secara layak. Hukum dalam pelaksanaannya dapat berlangsung secara damai, normal, tetapi dapat terjadi juga karena pelanggaran hukum. Dalam hal ini, pelanggaran terhadap hukum haruslah dijauhkan dan hukum harus ditegakkan, sehingga penegakan hukum menjadi kenyataan.

Penemuan hukum pada hakikatnya merupakan penemuan kembali sebuah esensi hukum yang terkandung di dalam peraturan hukum tertulis. Esensi hukum adalah ruh atau jiwa dari peraturan hukum itu sendiri. Penemuan terhadap esensi hukum memberikan pengetahuan terhadap apa fungsi dan tujuan hukum terapan, sehingga hakim dapat menegakkan fungsi dan tujuan hukum tersebut pada kasus-kasus yang ditanganinya.

Penemuan hukum pada prinsipnya harus mendasarkan pada sistem hukum yang ada. Penemuan hukum yang semata-mata mendasarkan pada undang-undang saja disebut sebagai system oriented, tetapi apabila sistem tidak memberikan solusi, maka sistem harus dikesampingkan dan menuju problemoriented. ${ }^{22}$

Wiarda mengemukakan sebagamana dikutip oleh Mertokusumo bahwa sistem penemuan hukum terbagi menjadi 2 bagian, yaitu penemuan hukum heteron dan penemuan hukum otonom. Penemuan hukum heteron adalah hakim dalam menangani perkara mendasarkan pada peraturan peraturan- peraturan diluar dirinya, seorang hakim tidak mandiri karena harus tunduk pada undang-undang. Artinya bahwa penemuan hukum ini tidak lain merupakan penerapan undang-undang yang secara logis-terpaksa sebagai silogisme. Sedangkan penemuan hukum otonom, hakim dibimbing oleh pandangan-pandangan atau pikirannya sendiri menurut apresiasi pribadi. Artinya hakim menjalankan fungsi yang mandiri dalam penerapan undang-undang terhadap peristiwa hukum yang konkret. ${ }^{23}$ Di sinilah kebebasan seorang hakim memutuskan

\footnotetext{
${ }^{22}$ Sutiyoso, Metode Penemuan Hukum, 62.

${ }^{23}$ Sudikno Mertokusumo, Mengenal Hukum: Suatu Pengantar, Edisi Revisi (Yogyakarta: Cahaya Atma Pustaka, 2010), 212.
} 
perkara dengan memegang teguh asas musyawarah majelis, memuat dasar atau alasan yang cukup dan mengadili seluruh bagian gugatan.

Negara Indonesia yang menganut hukum Kontinental mengenal penemuan hukum heteronom, yaitu sepanjang hakim terikat pada undang-undang, tetapi penemuan hukum ini mempunyai unsur otonom yang kuat, karena seringkali hakim harus menjelaskan atau melengkapi undang-undang menurut pandangannya sendiri. Sedangkan hukum precedent yang dianut negara-negara Anglo Saxon adalah hasil penemuan hukum otonom sepanjang pembentukan peraturan dan penerapan peraturan dilakukan oleh hakim, tetapi sekaligus bersifat heteronom, karena hakim terikat pada putusan-putusan terdahulu. ${ }^{24}$ Artinya seorang hakim tidak bisa memisahkan kedua sistem penemuan hukum tersebut dikarenakan kedua sistem tersebut sama-sama membantu hakim dalam melakukan menyelesaikan perkara. Mertokusumo berpendapat bahwa tidak ada batas yang tajam antara penemuan hukum yang heteronom dan otonom. Kenyataanya di dalam praktik penemuan hukum mengandung kedua unsur tersebut, yakni heteronom dan otonom. ${ }^{25}$

Praktik penemuan hukum oleh hakim pada umumnya dilakukan dengan maksud antara lain:

1. Menemukan sumber hukum mengenai kasus yang dihadapi, baik sumbernya dari hukum positif maupun sumber hukum tertulis lainnya di luar hukum positif.

2. Menemukan prakonsepsi obyek hukum yang dijadikan master plan atau pengandaian kasus oleh pembentuk peraturan hukum.

3. Menemukan dasar hukum mengenai kasus yang dihadapi dengan menggali kandungan hukum dari sumber-sumber tersebut, sehingga diketahui bagaimana ketentuan hukum yang dikandungnya.

4. Menemukan dasar hukum mengenai kasus yang dihadapi sebagai das solen, baik berupa ketentuan hukum yang bersifat umum, misalnya prinsip-prinsip atau nilainilai dasar sebagai hukum asal dan peraturan hukum terapan lainnya yang sudah ada sebagai hukum cabang, maupun praktik hukum dalam masyarakat sebagai hukum yang hidup.

\footnotetext{
${ }^{24}$ Ibid., 213.

${ }^{25}$ Ibid., 214.
} 
5. Menemukan cita hukum mengenai kasus yang dihadapi, yaitu tujuan akhir dari teks aturan hukum dimaksud, di mana cita hukum senantiasa bermuara pada keadilan.

6. Menemukan asas hukum mengenai kasus yang dihadapi guna pengembangan lebih lanjut dari hukum dasar menuju cita hukum untuk ditemukan illat (alasan) hukumnya.

7. Menemukan illat (alasan) hukum mengenai kasus yang dihadapi dan yang terkandung dalam teks hukum melalui metode penemuan hukum yang tepat.

8. Menemukan kesamaan illat (alasan) hukum pada kasus dan illat (alasan) hukum dalam teks hukum.

9. Merumuskannya menjadi hukum terapan baru yang mampu memberi perlindungan hukum dan keadilan, baik pada kasus yang dihadapi maupun pencari keadilan.

10. Melalui proses konkritisasi (individualisasi) diterapkan pada peristiwa konkrit sebagai das sein tertentu dengan memperhatikan kesamaan illat (alasan) hukum antara ketentuan hukum baru sebagai premis mayor dengan kasus konkrit sebagai premis minor.

11. Merumuskan amar putusan dan menerapkannya atas perkara yang dihadapi demi mewujudkan keadilan berdasarkan Ketuhanan Yang Maha Esa. ${ }^{26}$

Hakim dalam melakukan penafsiran suatu aturan hukum hendaknya mengacu pada prinsip-prinsipsebagai berikut:

1. Prinsip objektivitas yang mengisyaratkan bahwa penafsiran hendaknya berdasarkan pada arti dan hakikat secara literal dari aturan hukum dan harus dibuat jelas sehingga dapat digunakan untuk perkembangan selanjutnya.

2. Prinsip kesatuan yang mengisyaratkan setiap norma harus dibaca sebagai satu kesatuan teks yang tidak terpisah.

3. Prinsip genetis yang mengisyaratkan dalam melakukan penafsiran keberadaan teks asli harus menjadi pertimbangan utama demikian pula dengan tatabahasa, budaya dan kondisi sosial dari pembentukan hukum dan maksud dari pembuat hukum.

\footnotetext{
${ }^{26}$ Mukti Arto, Penemuan Hukum Islam Demi Mewujudkan Keadilan, Buku Kedua (Cet. I; Yogyakarta: Pustaka Pelajar, 2018), 250-251.
} 
4. Prinsip perbandingan yang mengisyaratkan dalam melakukan suatu penemuan perlu dilakukan perbandingan dengan teks hukum lainnya menyangkut hal yang sama di suatu waktu. ${ }^{27}$

Peristiwa hukum yang ditemukan oleh hakim dalam memeriksa perkara tidak semuanya ditemukan aturan hukum yang pas atau aturan hukum yang ada tidak relevan pada saat ini, sehingga terdapat lebih dari satu aturan hukum yang saling bertentangan mengatur fakta hukum yang bersangkutan, sehingga memerlukan pembaharuan sosial (social engineering). Hakim dalam hal ini diperkenankan menggunakan alat bantu untuk menemukan dan menentukan hukum yang menguasai fakta itu. Penggunaan alat bantu dalam penemuan hukum oleh hakim semata-mata dimaksudkan untuk penegakab hukum dan keadilan. Oleh karena itu menurut Tumpa bahwa penemuan hukum oleh hakim harus dilakukan sangat hati-hati, karena sering dalam praktik penemuan hukum itu disalah gunakan, yaitu sekedar mencari dasar pembenaran untuk keuntungan pihakpihak yang berperkara atau karena keberpihakan. ${ }^{28}$

Hakim dalam menemukan hukum dapat mencarinya dalam sumber-sumber penemuan hukum yang meliputi peraturan perundang-undangan (hukum tertulis), hukum tidak tertulis (kebiasaan), yurisprudensi, perjanjian internasional, doktrin (pendapat ahli hukum), dan perilaku manusia. ${ }^{29}$ Metode penemuan hukum oleh hakim dapat bermacam-macam, misalnya Manan membaginya dalam dua metode, yaitu metode interpretasi dan kontruksi. ${ }^{30}$ Kemudian diklasifikasikan dalam tiga kategori, yaitu metode interpretasi (interpretation), konstruksi hukum (legal contruction), dan rechtscheeping, law making). ${ }^{31}$ Menanggapi pengelompokan tersebut Asnawi berpendapat pembentukan dan penciptaan hukum merupakan bagian konstruksi hukum dikarenakan substansinya sama, yaitu menciptakan suatu hukum baru yang sama sekali

\footnotetext{
${ }^{27}$ Rodrigo, Fernandes Elias, "Penemuan Hukum dalam Proses Peradilan Pidana di Indonesia," Jurnal LPPM Bidang EkoSosBudKum, Volume 1 Nomor 1 Tahun 2014; 10.

${ }^{28}$ Harifin A. Tumpa, "Penerapan Konsep Rechtsvinding dan Rechtsschepping oleh Hakim dalam Memutus Suatu Perkara," Hasanudin Law Review, Volume 1, Nomor 2, Agustus 2015; 131; http://dx.doi.org/10.20956/halrev.v1i2.90

${ }^{29}$ Ahmad Ali, Menguak Tabir Hukum, 113.

${ }^{30}$ Abdul Manan, Penerapan Hukum Acara Perdata di Lingkungan Peradilan Agama (Jakarta: Kencana, 2006), 279 dan 281.

${ }^{31}$ Bagir Manan, "Beberapa Catatan tentang Penafsiran," Majalah Hukum Varia Peradilan, Tahun XXIV No. 285 Edisi Agustus 2009 (Jakarta: Ikatan Hakim Indonesia, 2009), 6.
} 
belum ada sebelumnya. ${ }^{32}$ Ini berarti sebuah hukum dapat berkembang berdasarkan hasil daripada interpretasi dan konstruksi hukum oleh pembuat hukum itu sendiri.

\section{Identifikasi Fakta Hukum Alasan Tuntutan Nafkah Istri Pasca Perceraian Putusan Nomor 419/Pdt.G/2016/PA.Lbt dan Putusan Nomor 618/Pdt.G/ 2018/PA.Lbt}

Pengadilan Agama sebagai lembaga yudikatif dalam struktur ketatanegaraan Indonesia memiliki fungsi dan peran strategis dalam memeriksa, memutus dan menyelesaikan sengketa yang terjadi di antara anggota masyarakat. Pemeriksaan suatu sengketa di muka Pengadilan khususnya perkara perdata, diakhiri dengan suatu putusan. Putusan Pengadilan bisa dalam bentuk positif (mengabulkan gugatan/tuntutan) atau dalam bentuk negatif (menolak gugatan/tuntutan), ${ }^{33}$ dan tidak terkecuali perkara perceraian yang diajukan di Pengadilan Agama.

Putusan yang dikabulkan dalam perkara perceraian berakibat pada putusnya hubungan suami istri antara pihak berperkara. Putusnya hubungan perkawinan ini menimbulkan hak dan kewajiban bagi mantan istri dan mantan suami. Mantan istri berhak menuntut nafkah yang dilalaikan suaminya selama masih terikat dalam perkawinan, berhak atas nafkah iddah dan mut'ah. Mantan suami berkewajiban untuk memenuhi nafkah yang dilalaikannya, memberikan nafkah iddah dan mut'ah. Pada perkara perceraian, khususnya cerai talak seringkali istri yang berkedudukan sebagai Termohon menuntut haknya untuk mendapatkan nafkah yang dilalaikan oleh suami (Pemohon) saat masih terikat dalam perkawinan, menuntut nafkah iddah, dan mut'ah.

Pengadilan Agama Limboto telah menerima dan memeriksa perkara permohonan cerai talak Nomor 419/Pdt.G/2016/PA.Lbt yang diputus oleh majelis hakim tanggal 26 April 2017 dan Nomor 618/Pdt.G/2018/PA.Lbt yang diputus pada tanggal 13 Februari 2019.

Pemeriksaan dan pemutusan suatu perkara ada tiga tahapan yang harus dilakukan oleh hakim yakni mengonstatasi, mengualifisir dan mengonstitusi. Tiga

\footnotetext{
${ }^{32}$ M. Natsir Asnawi, Hermeneutika Putusan Hakim: Pendekatan Multidisipliner dalam Memahami Putusan Peradilan Perdata (Cet. I; Yogyakarta: UII Press, 2014), 19.

${ }^{33}$ Putusan ditinjau dari tiga aspek, yakni dari aspek kehadiran para pihak, yaitu putusan gugur, putusan verstek, putusan coktradictoir. Dari aspek sifatnya yakni putusan deklarator, putusan constitutive dan putusan comdenatoir. Dari aspek waktu penjatuhannya, put usan sela dan putusan akhir.
} 
tahapan tersebut wajib bagi hakim untuk dilakukan. Dengan melakukan konstatir, hakim akan menemukan peristiwa hukum atau fakta hukum dari dalil yang diajukan oleh penggugat atau pemohon berdasarkan keterangan dalam tahap jawab menjawab dan bukti-bukti yang sah. Setiap tuntutan hukum/gugatan harus disertai dengan alasanalasan atau dalil-dalil yang biasanya disebut sebagai posita gugatan. Posita memuat fakta kejadian yang dijadikan dasar Penggugat mendalilkan memiliki hak atas sesuatu.

Pada Putusan Nomor 419/Pdt.G/2016/PA.Lbt, Pemohon bermaksud mengikrarkan talak kepada Termohon dengan dalil sejak 2016 rumah tangga Pemohon dan Termohon tidak lagi rukun disebabkan Ttermohon tidak menghargai dan melayani Pemohon sebagai kepala rumah tangga dan telah terjadi perselisihan antara orang tua Pemohon dengan Termohon hingga akhirnya pada bulan Juli 2016 Pemohon pergi dari rumah orang tua Termohon kembali dan tinggal di rumah orang tua Pemohon.

Pada persidangan, Termohon telah mengajukan jawaban membenarkan telah terjadi pertengkaran antara Pemohon dan Termohon namun membantah penyebab pertengkaran yang didalilkan oleh Pemohon. Termohon membenarkan telah terjadi perselisihan antara orang tua Pemohon dan orang tua Termohon disebabkan orang tua Pemohon menjual anak sapi yang harusnya menjadi bagian dari orang tua Termohon tanpa sepengetahuan orang tua Termohon, orang tua Termohon selalu ikut campur masalah rumah tangga Pemohon dan Termohon dan mengakui telah berpisah tempat tinggal sejak bulan Juli 2016 dan selama pisah, pemohon dua kali datang mengajak Termohon untuk tinggal bersama di kos-kosan, namun Termohon menolak karena untuk urusan makan, Pemohon akan makan di rumah orang tuanya, sedangkan Termohon makan di rumah orang tua Termohon. Selain itu orang tua Termohon tidak mengizinkan dikarenakan Termohon merupakan anak tunggal.

Terhadap jawaban Termohon tersebut, pemohon mengajukan replik ${ }^{34}$ membenarkan adanya pertengkaran masalah penjualan sapi mengakui pula dua kali mengajak Termohon untuk tinggal di kos-kosan, namun membantah adanya intervensi orang tua Pemohon dalam rumah tangga Pemohon dan Termohon. Kemudian

\footnotetext{
${ }^{34}$ Replik terdiri dari dua kata yakni re (kembali) dan pliek (menjawab). Replik merupakan lanjutan dari pemeriksaan suatu perkara perdata di pengadilan setelah tergugat mengajukan jawabannya. Dengan kata lain replik adalah jawaban/tanggapan Penggugat atas jawaban yang diajukan oleh Tergugat untuk meneguhkan dalil gugatannya.
} 
menanggapi replik Pemohon, Termohon mengajukan duplik ${ }^{35}$ mengenai bentuk intervensi orang tua Pemohon dalam rumah tangga Pemohon dan Termohon, setiap kali terjadi pertengkaran orang tua Pemohon akan datang menjemput Pemohon dan pernah mengatakan karena Pemohon dan Termohon sudah membeli mobil, sehingga uang seratus ribupun sudah tidak bisa diberikan kepada ibu Pemohon.

Selain itu terdapat pula Putusan Nomor 618/Pdt.G/2018/PA.Lbt dengan duduk perkaranya, yaitu Pemohon bermohon agar diizinkan untuk mengikrarkan talaknya kepada Termohon dengan dalil sejak awal menikah rumah tangganya sudah tidak rukun karena Termohon sering membentak Pemohon saat teman Pemohon datang berkunjung ke rumah, Termohon sudah memiliki laki-laki lain dan Termohon pergi meninggalkan Pemohon sejak bulan Mei 2012.

Terhadap dalil Pemohon tersebut, Majelis Hakim telah memberikan kesempatan kepada Termohon untuk mengajukan jawabannya. Dalam jawabannya Termohon mengakui adanya perselisihan dalam rumah tangga Pemohon dan Termohon, namun Termohon membantah sering membentak Pemohon saat ada teman Pemohon. Termohon marah kepada Pemohon karena Pemohon hanya bermain handphone dan tidak membantu Termohon mengurus anak-anak. Termohon menyangkal memiliki hubungan cinta dengan laki-laki lain dengan mengatakan bahwa yang sering menelpon Termohon adalah keluarga Termohon dari kampung, dan mengakui pada bulan Mei 2012 meninggalkan Pemohon karena Pemohon memukul Termohon dan untuk menyekolahkan anak-anak karena Pemohon tidak lagi peduli terhadap Termohon dan anak-anak serta Pemohon sudah menikah lagi dengan perempuan lain. Dalil bantahan Termohon tersebut ditangapi oleh Pemohon dalam repliknya yang pada pokoknya tetap pada permohonannya dengan tambahan pengakuan pernah memukul Termohon.

Setelah tahap jawab menjawab selesai, Majelis Hakim melanjutkan persidangan ke tahap pembuktian. Pada tahap ini, Pemohon telah mengajukan bukti surat dan tiga orang saksi. Demikian pula Termohon mengajukan bukti surat dan dua orang saksi

\footnotetext{
${ }^{35}$ Duplik adalah jawaban terhadap replik yang diajukan oleh Penggugat. Duplik ini diajukan oleh Tergugat untuk meneguhkan jawabannya yang pada lazimnya berisi tentang penolakan atas gugatan Penggugat.
} 
untuk menguatkan bantahannya pada persidangan di Pengadilan Agama Limboto. Majelis Hakim yang memeriksa perkara tersebut setelah mempertimbangkan buktibukti yang diajukan terhadap dalil perceraian, mengabulkan permohonan Pemohon dengan memberi izin kepada Pemohon untuk menjatuhkan talak satu raj'i terhadap Termohon di depan sidang Pengadilan Agama Limboto. Tahap konstatir pada perkara konvensi yang dilakukan oleh hakim tergambar pada tabel berikut:

Tabel 1

Tahapan Konstatir Konvensi Nomor 419/Pdt.G/2016/PA.Lbt

\begin{tabular}{|c|c|c|c|c|}
\hline No & Dalil Pemohon dan Termohon & $\begin{array}{c}\text { Jawab Menjawab } \\
\text { Diakui/Tidak }\end{array}$ & $\begin{array}{l}\text { Pembuktian } \\
\text { Terbukti/Tidak }\end{array}$ & $\begin{array}{c}\text { Fakta Hukum/ } \\
\text { Peristiwa Hukum }\end{array}$ \\
\hline \multirow[t]{6}{*}{1.} & Dalil Pemohon: & & & \\
\hline & $\begin{array}{l}\text { Perselisihan telah terjadi sejak tahun } \\
2016\end{array}$ & Diakui & Terbukti & Ya \\
\hline & $\begin{array}{l}\text { Termohon tidak menghargai } \\
\text { Pemohon }\end{array}$ & Dibantah & Tidak & Tidak \\
\hline & Termohon tidak melayani Pemohon & Dibantah & Tidak & Tidak \\
\hline & $\begin{array}{l}\text { Terjadi perselisihan antara orang tua } \\
\text { Pemohon dan Termohon }\end{array}$ & Diakui & Terbukti & Ya \\
\hline & $\begin{array}{l}\text { Telah pisah tempat tinggal sejak } \\
\text { bulan Juli } 2016 \text { karena Pemohon } \\
\text { kembali ke rumah orang tua Pemohon }\end{array}$ & Diakui & Terbukti & Ya \\
\hline \multirow[t]{7}{*}{2.} & Dalil Termohon : & & & \\
\hline & $\begin{array}{l}\text { Penjualan anak sapi yang harusnya } \\
\text { menjadi milik orang tua Termohon } \\
\text { oleh orang tua Pemohon tanpa } \\
\text { sepengetahuan orang tua Termohon }\end{array}$ & Diakui & Terbukti & Ya \\
\hline & $\begin{array}{l}\text { Orang tua termohon selalu } \\
\text { mencampuri urusan rumah tangga } \\
\text { Pemohon dan Termohon }\end{array}$ & Dibantah & Tidak & Tidak \\
\hline & $\begin{array}{l}\text { Selama pisah Pemohon dua kali } \\
\text { datang mengajak Termohon untuk } \\
\text { tinggal bersama di kos-kosan }\end{array}$ & Diakui & Tidak & Tidak \\
\hline & $\begin{array}{l}\text { Termohon tidak mau tinggal dengan } \\
\text { Pemohon dirumah kos karena } \\
\text { Termohon harus makan di rumah } \\
\text { orang tua Termohon dan Pemohon } \\
\text { makan di rumah orang tua Pemohon }\end{array}$ & Diakui & Tidak & Tidak \\
\hline & $\begin{array}{l}\text { Orang tua Termohon tidak } \\
\text { mengizinkan karena Termohon anak } \\
\text { tunggal }\end{array}$ & Diakui & Tidak & Tidak \\
\hline & $\begin{array}{l}\text { Pemohon minta izin untuk menikah } \\
\text { lagi }\end{array}$ & Diakui & Tidak & Tidak \\
\hline
\end{tabular}

Tabel 1 tergambar jelas bahwa 10 dalil Pemohon dan Termohon yakni 5 poin permohonan Pemohon dan 5 poin sanggahan Termohon hanya, 4 poin yang kemudian ditetapkan sebagai fakta hukum atau peristiwa hukum yakni perselisihan yang terjadi sejak tahun 2016, ada perselisihan antara orang tua Pemohon dan orang tua Termohon 
karena penjualan anak sapi milik orang tua Termohon dan pisah tempat tinggal sejak bulan Juli 2016. Selanjutnya tahap konstatir pada perkara konvensi Nomor 618/Pdt.G/2018/PA.Lbt sebagai berikut:

Tabel 2

Tahap Konstatir Konvensi Nomor 618/Pdt.G/2018/PA.Lbt

\begin{tabular}{|c|c|c|c|c|}
\hline No & Dalil Pemohon dan Termohon & $\begin{array}{c}\text { Jawab Menjawab } \\
\text { Diakui/Tidak }\end{array}$ & $\begin{array}{l}\text { Pembuktian } \\
\text { Terbukti/Tidak }\end{array}$ & $\begin{array}{l}\text { Fakta Hukum/ } \\
\text { Peristiwa Hukum }\end{array}$ \\
\hline \multirow[t]{7}{*}{1.} & Dalil Pemohon : & & & \\
\hline & $\begin{array}{l}\text { Perselisihan telah terjadi sejak awal } \\
\text { menikah }\end{array}$ & Diakui & Terbukti & Ya \\
\hline & $\begin{array}{l}\text { Termohon membentak Pemohon di } \\
\text { depan teman-teman Pemohon }\end{array}$ & Dibantah & Tidak & Tidak \\
\hline & Termohon tidak melayani Pemohon & Dibantah & Terbukti & Ya \\
\hline & Termohon sudah memiliki laki-laki lain & Dibantah & Tidak & Tidak \\
\hline & $\begin{array}{l}\text { Pemohon dan Termohon telah berpisah } \\
\text { tempat tinggal sejak bulan Mei } 2012\end{array}$ & Diakui & Terbukti & Ya \\
\hline & $\begin{array}{l}\text { Selama berpisah tempat tinggal } \\
\text { Pemohon dan Termohon tidak lagi } \\
\text { saling mengunjungi dan Termohon } \\
\text { tidak lagi memberikan nafkah kepada } \\
\text { Termohon }\end{array}$ & Diakui & Terbukti & Ya \\
\hline \multirow[t]{5}{*}{2.} & Dalil Termohon: & & & \\
\hline & $\begin{array}{l}\text { Pemohon hanya bermain handphone } \\
\text { jika Termohon minta bantuan kepada } \\
\text { Pemohon untuk membantu mengurus } \\
\text { anak }\end{array}$ & Dibantah & Tidak & Tidak \\
\hline & $\begin{array}{l}\text { Yang menelpon Termohon adalah } \\
\text { keluarga Termohon yang berada di } \\
\text { kampung }\end{array}$ & Dibantah & Tidak & Tidak \\
\hline & $\begin{array}{l}\text { Termohon meninggalkan Pemohon } \\
\text { karena Pemohon memukul Pemohon } \\
\text { dan tidak peduli lagi kepada } \\
\text { dan anak-anak }\end{array}$ & Diakui & Tidak & Tidak \\
\hline & $\begin{array}{l}\text { Pemohon sudah menikah lagi dengan } \\
\text { perempuan lain bernama Ama Arif }\end{array}$ & Diakui & Terbukti & Ya \\
\hline
\end{tabular}

Tabel 2 menunjukkan dalil permohonan Pemohon yang dinyatakan terbukti dan menjadi fakta hukum ada 4 yakni adanya perselisihan dalam rumah tangga Pemohon dan Termohon, Termohon tidak melayani Pemohon, serta pisah tempat tinggal sejak bulan Mei 2012 dan selaama pisah Pemohon dan Termohon tidak lagi saling mengunjungi dan tidak ada nafkah dari Pemohon untuk Termohon, sedangkan dalil bantahan termohon mengenai Pemohon yang sudah menikah dengan perempuan yang lain yang bernama Ama Arif telah terbukti dan dinyatakan sebagai fakta hukum. 
Dalam dua putusan perkara permohonan cerai talak di atas, Termohon telah mengajukan pula gugatan rekonvensi ${ }^{36}$ kepada pemohon. Dalam putusan nomor 419/Pdt.G/2016/PA.Lbt Termohon menuntut nafkah lalai sejumlah Rp.85.500.000,(delapan puluh lima juta lima ratus ribu rupiah) ${ }^{37}$, nafkah iddah sejumlah Rp.15.000.000,- (lima belas juta rupiah) dan mut'ah sejumlah Rp.50.000.000,- (lima puluh juta rupiah). ${ }^{38}$ Menanggapi tuntutan termohon ${ }^{39}$ tersebut, pemohon membantah telah lalai memberikan nafkah kepada termohon dengan alasan bahwa selama ini bahkan sampai dengan pisah tempat tinggal pemohon tetap memberikan nafkah kepada termohon walaupun hanya sisa dari gaji yang sudah dipotong pinjaman sebesar Rp.679.000,- (enam ratus tujuh puluh sembilan ribu rupiah), sehingga pemohon menolak untuk memberikan nafkah lalai kepada termohon. Terhadap nafkah iddah yang dituntut oleh termohon, pemohon hanya menyanggupi sejumlah Rp.200.000,(dua ratus ribu rupiah) dan mut'ah sejumlah Rp.300.000,- (tiga ratus ribu rupiah) karena pemohon tidak memiliki penghasilan lain selain dari gaji sebagai PNS sejumlah Rp.2.500.000,- (dua juta lima ratus ribu rupiah) yang telah dipotong dengan angsuran pinjaman, sehingga tersisa hanya Rp.679.000,- (enam ratus tujuh puluh sembilan ribu rupiah).

Sama halnya dalam perkara nomor 618/Pdt.G/2018/PA.Lbt, Termohon mengajukan pula gugatan rekonvensi berupa tuntutan nafkah lalai selama pisah tempat tinggal sejumlah Rp.30.000.000,- (tiga puluh juta rupiah) dan nafkah anak berkelanjutan untuk 3 orang anak sejumlah Rp.1.000.000,- (satu juta rupiah) setiap bulan. Menanggapi tuntutan balik dari termohon, pemohon menyatakan tidak mampu memenuhi tuntutan tersebut karena pemohon hanya bekerja sebagai kuli bangunan dengan penghasilan sejumlah Rp.70.000,- (tujuh puluh ribu rupiah) setiap hari, di samping pemohon juga bekerja sebagai tukang ojek.

\footnotetext{
${ }^{36}$ Gugatan rekonvensi adalah gugatan yang diajukan tergugat sebagai gugatan balasan terhadap gugatan yang diajukan Penggugat kepada Tergugat.

${ }^{37}$ Termohon menunt ut nafkah lalai selama 4 tahun pernikahan dan 6 bulan pisah tempat tinggal.

${ }^{38}$ Dalam putusan ini, Termohon menuntut nafkah lalai, nafkah iddah, mut'ah dan nafkah anak berkelanjutan.

${ }^{39}$ Dalam rekonvensi penyebutan pihak yang semula Pemohon menjadi Tergugat dan Termohon menjadi Penggugat. Namun agar lebih mudah memahami isi putusan dalam tulisn ini ditetapkan menuliskan penyebutan para pihak dengan Pemohon dan Termohon sebagaimana gugatan awal.
} 
Setelah melakukan konstatir pada gugatan rekonvensi pada Perkara Nomor 419/Pdt.G/2016/PA.Lbt, diperoleh fakta hukum bahwa Pemohon sudah menjalankan kewajibannya sebagai suami untuk menafkahi istri (Termohon), penghasilan Pemohon tersisa Rp.679.000,- (enam ratus tujuh puluh Sembilan ribu rupiah). Sedangkan dalam perkara nomor 618/Pdt.G/2018/PA.Lbt hakim memperoleh fakta hukum Pemohon telah lalai memberikan nafkah kepada Termohon selama pisah tempat tinggal sejak bulan Mei 2012 sampai dengan perkara diajukan oleh Pemohon dan Pemohon memiliki penghasilan Rp.70.000,- (tujuh puluh ribu rupiah) setiap hari sebagai kuli bangunan di luar penghasilan Pemohon sebagai tukang ojek. Fakta-fakta hukum inilah yang kemudian akan ditemukan hukumnya oleh hakim pada tahap kualifisir.

\section{Metode Interpretasi dalam Penentuan Pembebanan Nafkah Istri Pasca Perceraian Pada Perkara Nomor 419/Pdt.G/2016/PA.Lbt dan Perkara Nomor 618/Pdt.G/2018/PA.Lbt}

Motode interpretasi terbagi atas tujuh metode, yakni metode interpretasi subsumtif, interpretasi gramatikal, interpretasi historis, interpretasi sosiologis, interpretasi ekstensif, interpretasi restriktif dan interpretasi sistematis. ${ }^{40}$ Dari beberapa jenis metode interpretasi atau penafsiran tersebut, Hakim dalam menemukan hukum pada perkara cerai talak baik dalam Putusan Nomor 419/Pdt.G/2016/PA.Lbt maupun Putusan Nomor 618/Pdt.G/2018/PA.Lbt, untuk mengabukan permohonan cerai talak dari para Pemohon menggunakan pendekatan interpretasi subsumtif dengan melakukan penerapan suatu teks peraturan perundang-undangan terhadap kasus yang ditanganinya dengan menggunakan silogisme. Dalam Putusan Nomor 419/Pdt.G/2016/PA.Lbt misalnya, hakim menemukan premis mayornya perceraian bisa terjadi karena telah terjadi perselisihan dan pertengkaran yang sifatnya sudah terus menerus dan sudah sulit untuk dirukunkan kembali, premis minornya adalah fakta hukum rumah tangga Pemohon dan Termohon sudah tidak rukun sejak 2016 karena perselisihan antara orang tua Pemohon dan Termohon yang menyebabkan Pemohon dan Termohon pisah tempat tinggal sejak bulan Juli 2016. Selanjutnya hakim menarik konklusi perselisihan antara orang tua Pemohon dan Termohon menyebabkan Pemohon

\footnotetext{
${ }^{40}$ Sutiyoso, Metode Penemuan Hukum, 79.
} 
dan Termohon juga berselisih dan bertengkar hingga berpisah tempat tinggal bahkan telah diupayakan rukun oleh hakim namun tidak berhasil sehingga perselisihan Pemohon dan Termohon tersebut sudah berada pada tingkat yang susah untuk dirukunkan kembali. Berdasarkan konklusi tersebut maka hakim mengabulkan permohonan Pemohon untuk bercerai dengan Termohon. Metode pendekatan yang sama juga dilakukan oleh hakim dalam put usan nomor 618/Pdt.G/2018/PA.Lbt.

Demikian pula dalam menentukan layak tidaknya Termohon memperoleh nafkah dari Pemohon dalam putusan nomor 618/Pdt.G/2018/PA.Lbt. Premis mayornya istri tidak berhak mendapat nafkah dari suami jika istri tersebut nusyüz. Premis minornya Termohon sebagai istri tetap menjalankan kewajibannya merawat anak Pemohon dan Termohon serta meninggalkan Pemohon untuk menghindari konflik yang lebih besar lagi bahkan saat ini Pemohon sudah menikah lagi dengan perempuan lain. Kemudian hakim mengambil konklusi kondisi pisah kepergian Termohon dari rumah orang tua Termohon bukan merupakan perbuatan nusyuz istri namun untuk menghindari konflik yang lebih besar dengan Pemohon dan selama berpisah Termohon tetap menjalankan kewajibannya mengasuh dan merawat tiga orang anak Pemohon dan Termohon. Sebaliknya setelah berpisah Pemohon yang melakukan pernikahan dengan perempuan lain. Dengan tidak nusyünya Termohon, maka termohon berhak untuk mendapatkan nafkah dari Pemohon. Setelah mengambil kesimpulan tersebut, maka hakim menetapkan menghukum Pemohon untuk membayar nafkah lalai, nafkah iddah dan mut'ah kepada Termohon.

Hakim dalam mengabulkan permohonan cerai Pemohon, hakim melakukan cara berpikir logis dengan mengambil kesimpulan dari hal-hal yang bersifat umum (premis mayor) untuk diterapkan terhadap hal-hal yang bersifat khusus (premis minor). Dengan kata lain, memasukan aturan atau teks undang-undang ke dalam perkara yang sedang diadili.

Berkaitan dengan besaran nafkah yang akan dibebankan kepada Pemohon pada dua putusan di atas, hakim melakukan pendekatan interpretasi gramatikal. Pada Putusan Nomor 419/Pdt.G/2016/PA.Lbt untuk menentukan besaran nafkah pada putusan ini, hakim merujuk pada Pasal 80 Ayat (4) KHI “sesuai dengan penghasilannya 
suami menanggung : a...."41 Frasa "penghasilan” dalam pasal tersebut dipahami hakim sebagai gaji bagi PNS dan pegawai swasta lainnya. Dalam kasus ini karena Pemohon adalah seorang PNS, maka penghasilan Pemohon adalah gaji Pemohon. Dalam pemeriksaan ternyata ditemukan fakta hukum bahwa Pemohon memiliki hutang pada salah satu bank dan setelah dikurangi kewajiban hutangnya tersebut ternyata gaji yang didapatkan Pemohon tinggal Rp.679.000,-. Sehingga berdasarkan gaji bersih dari Pemohon tersebut hakim menentukan besaran pembebanan nafkah iddah untuk Termohon sejumlah Rp.3.000.000,- dan mut'ah sejumlah Rp.2.000.000,-.

Nampak bahwa pada putusan di atas, Hakim menafsirkan penghasilan dengan hanya melihat pada gaji bersih yang didapat oleh Pemohon. Penafsiran tersebut berangkat dari pengertian penghasilan itu sendiri yang berarti pendapatan, perolehan (uang yang diterima, dan sebagainya). Makna penghasilan tidak hanya terbatas pada gaji seseorang, melainkan juga hasil dari pekerjaan-pekerjaan sampingan lainnya dan juga usaha-usaha yang dilakukan seseorang juga dikategorikan sebagai penghasilan. Bahkan mungkin penghasilan yang didapat dari pekerjaan sampingan atau usaha-usaha jauh lebih besar dari pada gaji sebagai PNS. Dalam kasus ini hakim mendasari pendapatnya karena hakim melihat Pemohon hanya memiliki penghasilan dari gaji sebagai PNS serta mempertimbangkan pula kemampuan pemohon melaksanakan amar putusan tersebut, sebagaimana pendapat dari Himawan berikut:

Sebenarnya ketika seorang istri menuntut nafkah kepada suami, diikuti pula dengan harapan bahwa apa yang mereka tuntut tersebut benar-benar diperolehnya. Artinya tuntutan tersebut harus disesuaikan dengan kesanggupan suami. Ketika nilai yang dibebankan kepada suami besar, bisa saja istri merasa senang, akan tetapi ternyata beban tersebut tidak sanggup dipenuhi oleh suami maka nilai yang besar tersebut sia-sia saja karena pada akhirnya istri tidak mendapatkan apa-apa. ${ }^{42}$

Hakim dalam Putusan Nomor 618/Pdt.G/2018/PA.Lbt mengabulkan gugatan Termohon berdasarkan kemampuan senyatanya yang diperoleh Pemohon dan kemampuan potensial yang dimiliki oleh Pemohon dengan melihat usia, kecakapan,

\footnotetext{
${ }^{41}$ Bunyi lengkap pasal 80 Ayat (4) KHI sebagai berikut : "sesuai dengan penghasilannya suami menanggung : a. nafkah, kiswah dan tempat tinggal bagi istri; b. biaya rumah tangga, biaya perawatan dan pengobatan bagi istri dan anak; c. biaya pendidikan bagi anak."

${ }^{42}$ Himawan Tatura Wijaya, S.H.I. Hakim Pengadilan Agama Marisa. Wawancara pada tanggal 24 Agustus 2019.
} 
dan kondisi fisik dari Pemohon. Pada kasus ini hakim memahami "penghasilan" dalam pasal 80 ayat (4) sebagai bagian dari “kemampuan” yang dimaksud pada ayat (2) pasal tersebut.

Berkaitan dengan pasal 80 ayat (2) KHI tersebut, hakim melakukan penafsiran berdasarkan pada makna teks undang-undang menurut bahasa. Pada putusan ini hakim memaknai kemampuan sebagaimana arti yaitu kesanggupan, kecakapan, kekuatan dan kekayaan sehingga kemampuan suami tidak hanya terbatas pada gaji suami saja semata namun juga termasuk potensi-potensi yang dimilikinya. Sebagaimana terlihat dalam argumentasi hukum hakim berikut dalam perkara tersebut:

Menimbang, bahwa perihal kemampuan Tergugat untuk memenuhi tanggung jawab memberi nafkah kepada Penggugat dan anaknya, Majelis Hakim membedakan antara kemampuan aktual dan kemampuan potensial.

Menimbang, bahwa yang dimaksudkan sebagai kemampuan aktual dalam hal ini adalah kemampuan Tergugat menurut keadaannya secara riil, yang berdasarkan fakta saat ini bekerja sebagai kuli bangunan dengan gaji harian kurang lebih Rp. 70.000 ,- (tujuh puluh ribu rupiah) per hari, selain itu juga Tergugat bekerja sebagai tukang ojek, Karena itu, secara aktual Tergugat harus dinilai sebagai orang yang mempunyai pekerjaan.

Menimbang, bahwa adapun yang dimaksudkan Majelis Hakim sebagai kemampuan potensial yaitu kemampuan Tergugat menurut kadar potensinya untuk bekerja, berpenghasilan, dan mendapatkan harta benda. Potensi tersebut dinilai menurut keadaan fisik, usia, dan lain-lain yang menurut kelaziman mempengaruhi peluang seseorang untuk dapat bekerja dan berpenghasilan.

Menimbang, bahwa Tergugat ternyata masih berumur 36 tahun, merupakan usia produktif dan tidak terbukti mengalami cacat fisik yang bersifat permanen. Dengan demikian, Tergugat tergolong mampu secara potensial dengan yang masih diusia produktif, dan tidak terhalang secara fisik untuk bekerja dan berpenghasilan lebih dari pada yang biasanya.

Menimbang, bahwa berdasarkan pertimbangan mengenai kedua kategorisasi kemampuan tersebut, Majelis Hakim berkesimpulan bahwa Tergugat adalah orang yang pada dasarnya mempunyai kemampuan secara aktual, dan memiliki kemampuan secara potensial, maka dalam menetapkan pembebanan tersebut, keadaan Tergugat tersebut dapat dijadikan sebagai pertimbangan bagi Majelis Hakim dalam menetapkan nominal kewajiban yang dibebankan kepada Tergugat sebagaimana dipertimbangkan selanjutnya.

Meskipun kedua putusan di atas sama-sama menggunakan metode interpretasi gramatikal, namun pada Putusan Nomor 419/Pdt.G/2016/PA.Lbt hanya mendasarkan pada pasal 80 Ayat (4) KHI dan kemudian memaknai kata "penghasilan” dalam pasal 
tersebut sebagai gaji bersih yang diterima oleh suami. Sedangkan pada Putusan Nomor 618/Pdt.G/2018/PA.Lbt, hakim menggunakan pasal 80 ayat (2) dan (4) dengan memaknai kata "kemampuan" dalam ayat (2) sebagaimana arti dari kata tersebut sehingga "penghasilan" dalam ayat (4) pasal tersebut merupakan salah satu jenis dari kemampuan suami. Di sinilah yang menjadikan adanya perbedaan putusan dalam penentuan besaran nafkah istri pasca perceraian di Pengadilan Agama Limboto.

\section{E. Kesimpulan}

Keberadaan Pengadilan Agama Limboto sebagai peradilan yang memiliki koridor independensi yang merdeka, maka di dalam menerima, memutus dan menyelesaikan perkara sangatlah penting dan strategis. Para hakim dalam memutuskan perkara penentuan nafkah istri pasca perceraian mempertimbangkan prinsip keadilan bagi pihak berperkara. Pada Putusan Nomor 419/Pdt.G/2016/PA.Lbt, hakim Pengadilan Agama Limboto mempertimbangkan pada aspek kemampuan riil pada mantan suami. Sedangkan pada Putusan Nomor 618/Pdt.G/2018/PA.Lbt, hakim Pengadilan Agama Limboto mempertimbangkan pada aspek kemampuan potensial mantan suami. Dalam artian penggunaan interpretasi gramatikal.

Penerapan hukum oleh hakim merupakan upaya penting dalam rangka untuk melengkapi kekurangan sumber hukum dengan cara menggali sumber-sumber hukum di luar undang-undang, yaitu nilai-nilai yang hidup di masyarakat. Penerapan hukum hakim Pengadilan Agama Limboto dalam penetapan nafkah istri pasca perceraian adalah penetapan pemenuhan nafkah iddah, mut'ah dan nafkah lalai mempertimbangkan kemampuan suami, baik secara aktual maupun potensial, juga mempertimbangkan kemampuan istri memenuhi kebutuhannya sendiri. Kemampuan potensial ini memperhatikan kondisi fisik, batas umur produktif, pendidikan dan keahlian mantan suami yang dapat menghasilkan pendapatan yang lebih besar.

\section{Daftar Pustaka}

Ali, Ahmad. Menguak Tabir Hukum, Edisi Kedua. Jakarta: Kencana, 2015.

Arto, Mukti. Penemuan Hukum Islam Demi Mewujudkan Keadilan, Buku Kedua. Cet. I; Yogyakarta: Pustaka Pelajar, 2018. 
Asnawi, M. Natsir. Hermeneutika Putusan Hakim: Pendekatan Multidisipliner dalam Memahami Putusan Peradilan Perdata. Cet. I; Yogyakarta: UII Press, 2014.

Bisri, Cik Hasan. Peradilan Agama di Indonesia. Jakarta: Raja Grafindo Persada, 2003.

Darwis, Rizal. Nafkah Batin Isteri dalam Hukum Perkawinan. Gorontalo: Sultan Amai Press, 2015.

Hidayat, Arif. "Penemuan Hukum Melalui Penafsiran Hakim dalam Putusan Pengadilan," Pandecta, Volume 8, Nomor 2, Juli 2013.

Manan, Abdul. Penerapan Hukum Acara Perdata di Lingkungan Peradilan Agama. Jakarta: Kencana, 2006.

. "Beberapa Catatan tentang Penafsiran," Majalah Hukum Varia Peradilan, Tahun XXIV No. 285 Edisi Agustus 2009. Jakarta: Ikatan Hakim Indonesia, 2009.

Marzuki, Peter Mahmud. Pengantar Ilmu Hukum, Ed. Revisi. Jakarta: Kencana, 2008.

Mertokusumo Sudikno, dan A. Pitlo, Bab-Bab tentang Penemuan Hukum. Jakarta: PT Citra Aditya Bakti, 1993.

. Penemuan Hukum: Sebuah Pengantar, Ed. II. Cet. VI; Yogyakarta: Liberty, 2009.

. Mengenal Hukum: Suatu Pengantar, Edisi Revisi. Yogyakarta: Cahaya Atma Pustaka, 2010.

Nasution, Muhammad Syukri Albani. Hukum dalam Pendekatan Filsafat. Cet. I; Jakarta: Kencana, 2016.

Panggabean, H.P. Penerapan Teori Hukum dalam Sistem Peradilan Indonesia. Bandung: PT. Alumni, 2014.

Republik Indonesia, Instruksi Presiden Nomor 1 Tahun 1999 tentang Kompilasi Hukum Islam.

Republik Indonesia. Undang-Undang Nomor 1 Tahun 1979 tentang Perkawinan, dalam Zainal Abidin, Kumpulan Peraturan Perundang-Undangan dalam Lingkungan Peradilan Agama. Cet. 3; Jakarta: Yayasan al-Hikmah, 1993.

Republik Indonesia. Undang-Undang Nomor 3 Tahun 2006 tentang Perubahan Atas Undang-Undang Nomor 7 Tahun 1989 tentang Peradilan Agama.

Republik Indonesia. Undang-Undang Nomor 48 Tahun 2009 tentang Kekuasaan Kehakiman.

Rodrigo, Fernandes Elias, "Penemuan Hukum dalam Proses Peradilan Pidana di Indonesia," Jurnal LPPM Bidang EkoSosBudKum, Vol. 1 No. 1 Tahun 2014.

Sutiyoso, Bambang. Metode Penemuan Hukum. Yogyakarta: UII Press, 2012.

Tumpa, Harifin A. "Penerapan Konsep Rechtsvinding dan Rechtsschepping oleh Hakim dalam Memutus Suatu Perkara," Hasanudin Law Review, Volume 1, Nomor 2, Agustus 2015; http://dx.doi.org/10.20956/halrev.v1i2.90 